\title{
Heterotrophic protists as a trophic link between picocyanobacteria and the pearl oyster Pinctada margaritifera in the Takapoto lagoon (Tuamotu Archipelago, French Polynesia)
}

\author{
Pascale Loret ${ }^{1, *}$, Solange Le Gall ${ }^{2}$, Christine Dupuy ${ }^{2,3}$, Jean Blanchot ${ }^{4}$, \\ Annie Pastoureaud ${ }^{2}$, Bruno Delesalle ${ }^{1}$, Xavier Caisey ${ }^{5}$, Gérard Jonquières ${ }^{5}$ \\ ${ }^{1}$ EPHE, URA-CNRS 1453, Université de Perpignan, 66860 Perpignan Cédex, France \\ ${ }^{2}$ CREMA, BP 5, 17137 L'Houmeau, France \\ ${ }^{3}$ LBEM, Université de La Rochelle, Pôle Science, Avenue Michel Crépeau, 17042 La Rochelle, France \\ ${ }^{4}$ IRD, Station Biologique de Roscoff, BP 74, 29682 Roscoff, France \\ ${ }^{5}$ IFREMER/COP, BP 7004 Taravao, Tahiti, French Polynesia
}

\begin{abstract}
Pearl oysters are farmed in oligotrophic tropical atoll lagoons where planktonic communities are dominated by production from cyanobacteria smaller than $2 \mu \mathrm{m}$. Paradoxically, the pearl oyster Pinctada margaritifera only retains particles larger than $2 \mu \mathrm{m}$. In this study, we assess the relative contribution of hetero/mixotrophic microbiota to the available planktonic resource. In Takapoto Atoll, picocyanobacteria are the dominant biomass $\left(20 \mu \mathrm{g} \mathrm{Cl}^{-1}\right)$. The carbon biomass of ciliates and dinoflagellates ranges from 1 to 24 and 0.5 to $5 \mu \mathrm{g} \mathrm{Cl}^{-1}$ respectively, with a mean of $6 \mu \mathrm{g} \mathrm{Cl}^{-1}$ for ciliates and $2 \mu \mathrm{g} \mathrm{Cl}^{-1}$ for dinoflagellates. The possible retention by $P$. margaritifera on a natural protist suspension was investigated. Due to its high clearance rates $\left(\mathrm{ca} 20 \mathrm{l} \mathrm{h}^{-1} \mathrm{~g}^{-1}\right)$ the pearl oyster retained $85 \mu \mathrm{g} \mathrm{C} \mathrm{h}^{-1} \mathrm{~g}^{-1}$ from ciliates and $65 \mu \mathrm{g} \mathrm{C} \mathrm{h}^{-1} \mathrm{~g}^{-1}$ from dinoflagellates. Conversely, cyanobacteria were not efficiently retained by the bivalve and did not efficiently contribute to its diet. From our experiments, we concluded that hetero/mixotrophic protists rapidly and efficiently process the picoplanktonic resource towards filter-feeders, particularly pearl oysters.
\end{abstract}

KEY WORDS: Protists · Atoll lagoon · Pearl oysters · Pinctada margaritifera $\cdot$ Picoplankton $\cdot$ Trophic resource

Resale or republication not permitted without written consent of the publisher

\section{INTRODUCTION}

Heterotrophic or mixotrophic protists are known to play a key role in marine ecosystems (Pomeroy 1974). They consume bacteria and phytoplankton and are preyed upon by zooplanktonic organisms, particularly by copepods (Berk et al. 1977). Protists have been suggested to be a major trophic link between picoplankters and planktonic metazoa (Porter et al. 1979, Azam

*Present address: Department of Oceanography, Texas A\&M University, 3146 TAMU, College Station, Texas 77843-3146, USA. E-mail: ploret@ocean.tamu.edu et al. 1983, Sherr et al. 1986). Moreover, recent studies demonstrated that ciliates and flagellates are retained by the oyster Crassostrea gigas (Le Gall et al. 1997, Dupuy et al. 1999). Heterotrophic protists may thus represent a valuable trophic link between bacterioplankton and these benthic suspension-feeders.

In French Polynesia, farming of the pearl oyster Pinctada margaritifera has been developped in atoll lagoons. The pearl oyster is a filter-feeder which obtains energy resources by actively clearing organic particles (e.g. phytoplankton) from the water (Herdman 1903, Mansour \& Gabal 1980, Nasr 1984, Hawkins et al. 1998, Loret 1999, Pouvreau et al. 1999). The phytoplanktonic communities of atoll lagoons are known to 
be dominated by organisms smaller than $2 \mu \mathrm{m}$. In such ecosystems, more than $60 \%$ of the primary biomass and production is achieved by picocyanobacteria and autotrophic picoeukaryotes (Charpy et al. 1992, Charpy 1996, Charpy \& Blanchot 1996, 1998). These lagoons are also characterized by a high biomass of slow-growing bacteria (Blanchot et al. 1989, Dufour \& Torréton 1995). Paradoxically, pearl oysters do not efficiently retain particles smaller than $2 \mu \mathrm{m}$ diameter (Jonquières et al. 1994, Torréton \& Dufour 1996, Pouvreau et al. 1999, Yukihira et al. 1999). As a consequence, both cyanobacteria and bacteria are not accessible to them. Additionally, in these oligotrophic lagoons, nanophytoplankter production is insufficient to balance the energy budget of pearl oysters, even though their high pumping activity is taken into account to make up for the poor lagoonal energy resources (Pouvreau et al. 1999). Evidence of a trophic link between picoparticles and pearl oysters would partly explain the paradoxical growth of Pinctada margaritifera in oligotrophic Polynesian atolls dominated by unavailable picoplanktonic production.

The protist communities in atoll lagoons have been rarely investigated (Blanchot et al. 1989, González et al. 1998, Sakka 1999). The aim of this study was: (1) to evaluate the importance of hetero/mixotrophic protists as a potential energy resource in the lagoon, and (2) to estimate their contribution to the diet of pearl oysters. Experiments were carried out through 2 complementary approaches: a quantitative and taxonomic study of protists communities in the Takapoto lagoon and an experimental study of retention and ingestion of picoplankton and protist ciliates by pearl oysters.

\section{MATERIALS AND METHODS}

Study site. The study was conducted in Takapoto Atoll between 1 and 10 February 1998. Takapoto Atoll $\left(14^{\circ} 30^{\prime} \mathrm{S}, 145^{\circ} 20^{\prime} \mathrm{W}\right)$ is located in the Tuamotu Archipelago, in the north of French Polynesia. The lagoon has a surface area of $81 \mathrm{~km}^{2}$ and the average depth is $25 \mathrm{~m}$ (Ricard et al. 1979). The main feature of this atoll is the absence of a pass, which restricts water flow between the lagoon and the ocean (Fig. 1). The residence time of water in the lagoon was estimated to be 4.2 yr (Sournia \& Ricard 1976). Mean water temperature and salinity are $28.6 \pm 1.5^{\circ} \mathrm{C}$ and $38.3 \pm 0.5 \mathrm{psu}$ respectively, and the physical-chemical parameters are fairly homogeneous (Pouvreau et al. 2000). Meteorological conditions were unusual during 2 days at the beginning of the survey, due to the tropical storm Veli.

Sampling, enumeration and characterization of lagoonal planktonic communities. Spatial distribution of protists was studied on 2 February 1998 at 4 stations
(Fig. 1), at 3 depths (surface, 10 and $20 \mathrm{~m}$ ). Temporal variation was followed every $6 \mathrm{~h}$ during a diel cycle at Stn 4 at the 3 depths. The water was collected using a 51 Niskin sampling bottle, and stored in an opaque carboy at field temperature (isotherm box) until use in the laboratory. Ciliates and dinoflagellates were fixed, stained and enumerated according to methods modified from Haas (1982) and Sherr et al. (1994). They were enumerated in Utermöhl settling chambers (Hydro-Bios combined plate chambers), using an inverted epifluorescence microscope (Zeiss Axiovert 135, $100 \mathrm{~W}$ mercury lamp and blue light excitation). Taxa were identified under combined epifluorescence and interference contrast illumination. Cell sizes (length and width) were measured using a calibrated ocular micrometer. The mean cell volume of each taxon was calculated by equating the shape of the cytoplasm to standard geometric configurations. Protist biovolumes were converted into carbon units, using a theoretical carbon/volume ratio of $0.17 \mathrm{pg} \mathrm{C} \mathrm{m}^{-3}$ (Putt \& Stoecker 1989, corrected for glutaraldehyde fixative, according to Leakey et al. 1994). Heterotrophic nanoflagellates were not enumerated because of an accidental injury in preserved samples.

Isolation and culture of a ciliate and a cyanobacterium from the lagoon. In order to evaluate the importance of ciliates in energy transfer within the microbial food web of the lagoon, the first step was to estimate their growth rate and growth efficiency. Therefore,

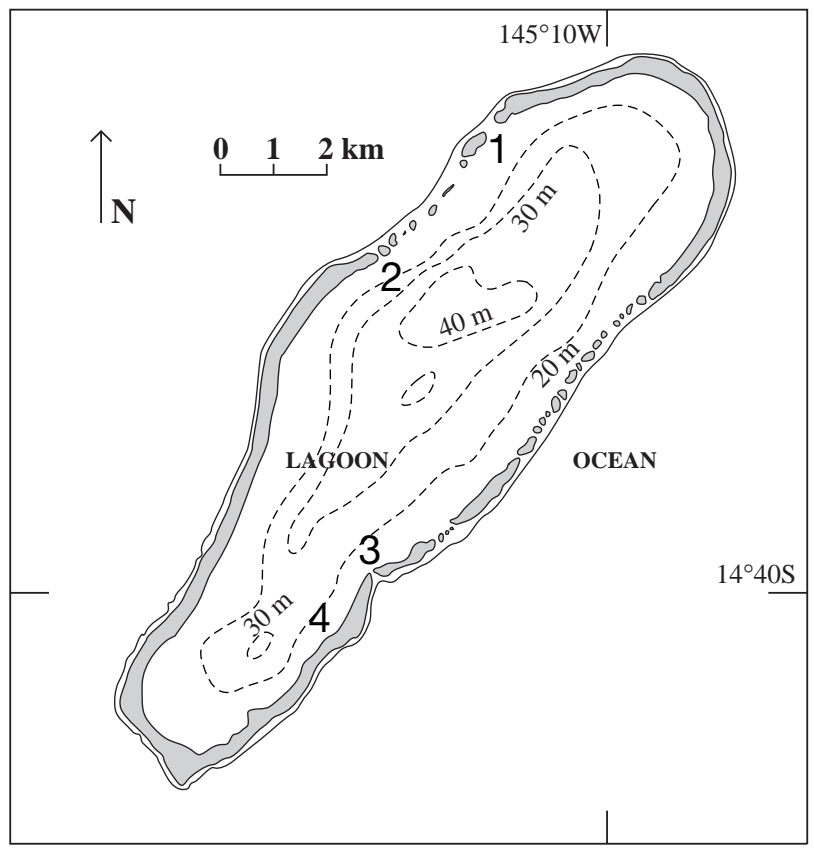

Fig. 1. Location of the 4 sampling sites in the Takapoto lagoon (Stns 1, 2, 3, and 4), French Polynesia, studied between 1 and 10 February 1998 
during a preliminary survey (in April 1997) ciliates and their picoplanktonic prey were sampled in the southern part of the lagoon. A ciliate was isolated as a clonal strain and cultured according to Hamilton \& Preslan (1969) and Caron et al. (1991), on a mixed bacterial assemblage grown on a nutrient medium promoting bacterial growth (TSB/NaCl, Sigma). The taxonomic identification of the ciliate Protocruzia sp. was done on protargol-stained cells. An heterotrophic bacterial community from the same lagoonal water aliquot was cultured on the nutrient medium (TSB/NaCl from Sigma) and 2 bacterial strains were isolated and maintained in culture. Bacterial enumeration was carried out according to Porter \& Feig (1980).

Autotrophic picoplankton was isolated by gravity filtration of a lagoonal water sample from Stn 4, through a $0.6 \mu \mathrm{m}$ Nuclepore filter, and inoculated in a set of sterile polycarbonate flasks with increasing dilutions $(1 / 1$ to $1 / 100000)$ of $f / 20$ culture medium (recipe according to Guillard \& Ryther 1962, without copper). Isolates were incubated under a moderate blue light $\left(20 \mu \mathrm{E} \mathrm{m} \mathrm{m}^{-2} \mathrm{~s}^{-1}\right)$ at $28^{\circ} \mathrm{C}$. Picoplanktonic growth was followed by enumeration under epifluorescence microscope or flow cytometric analysis (Charpy \& Blanchot 1996). Aliquots of each culture were analysed for autotrophic picoplankton characterization in a FACScan flow cytometer (Blanchot \& Rodier 1996). A strain of Synechococcus (TAK 9802) was isolated by serial dilution in PCRS11 culture medium (Partensky et al. 1999). Every $15 \mathrm{~d}, 1 \mathrm{ml}$ of exponential growth phase culture was transferred to $19 \mathrm{ml}$ of fresh culture medium and incubated. Pigments were analysed by high performance liquid chromatography (HPLC), according to Wright et al. (1991).

In vitro determination of growth rate and gross growth efficiency of a lagoonal ciliate. The growth of Protocruzia sp. was studied under culture conditions. In order to estimate the ability of lagoonal bacteria and cyanobacteria to support the growth of this protist, several types of picoprey were used, i.e. 2 lagoonal heterotrophic bacterial strains (BS1, BS2) and 2 autotrophic cyanobacterial strains, Synechococcus TAK 9802 (from the Takapoto lagoon) and Synechococcus $\mathrm{ROSCO}_{4}$ (from the Atlantic Ocean). Different concentrations of

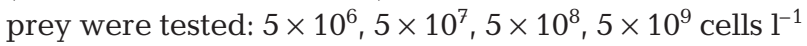
and the optimal concentration of $10^{8}$ cells $\mathrm{l}^{-1}$ was used for all prey in the growth rate estimations. Culture experiments of Protocruzia sp. were performed in Falcon multiwell culture plates, allowing independent triplicates. Ciliates in log-phase growth were separated from their bacterial prey by differential centrifugation at $800 \times g$ and at $4^{\circ} \mathrm{C}$ for 10 min (Ohman \& Snyder 1991), and resuspended in sterile sea water (300 cells $\mathrm{ml}^{-1}$ ). Each $4 \mathrm{ml}$ well was filled with 900 ciliates in $3 \mathrm{ml}$ sterile sea water. Food items were taken from log-phase cultures, sedimented by centrifugation $\left(10000 \times g, 4^{\circ} \mathrm{C}\right.$ for $\left.30 \mathrm{~min}\right)$, washed twice in phosphate-buffered saline (PBS) and resuspended in sterile sea water. Control treatments consisted of ciliate suspension without any picoprey. The ciliate abundance was followed for 2 d using a Malassez couting cell (Polylabo). The duration of the exponential growth phase of Protocruzia sp. was previously determined in culture by a growth kinetic experiment. The specific growth rate and generation time of Protocruzia sp. was evaluated during the exponential growth phase (Heinbokel 1978):

$$
C_{t}=C_{0} \mathrm{e}^{\mu \cdot t} \text { with } \mu=\left(\ln C_{t}-\ln C_{0}\right) / t
$$

where $C_{t}=$ ciliate number at the end of the exponential phase $\left(\right.$ cells $\left.\mathrm{l}^{-1}\right), C_{0}=$ ciliate number at the beginning of the exponential phase (cells $\mathrm{l}^{-1}$ ), $\mu=$ growth rate $\left(\mathrm{h}^{-1}\right)$, and $t=$ time interval $(\mathrm{h})$.

The generation time $(G)$ was estimated from $\mu$ :

$$
G=(\ln 2) / \mu
$$

The gross growth efficiency $(E)$ was evaluated for Synechococcus TAK 9802 from the proportion of produced ciliate biomass versus the consumed picoplanktonic prey biomass.

$$
E(\%)=\frac{\text { ciliate production }(\mu \mathrm{g} C)}{\text { picoprey consumption }(\mu \mathrm{g} C)}
$$

The carbon cell contents used for the estimations of picophytoplankton biomass were $178 \mathrm{fg} \mathrm{C}^{\mathrm{C}} \mathrm{cell}^{-1}$ for Synechococcus and $60 \mathrm{fg} \mathrm{C}$ cell $^{-1}$ for Prochlorococcus from the Takapoto lagoon (Charpy \& Blanchot 1998).

Experimental study of pearl oyster grazing. A preliminary set of experiments were conducted in order to investigate the possible retention of picophytoplankton by the pearl oysters. The experimental device was made of metacrylate chambers (volume: 8 l) filled with a natural picoplanktonic consortium (i.e. Prochlorococcus, Synechococcus and pico/nanoeukaryotes) taken from Stn 4, at $5 \mathrm{~m}$ depth. Pearl oysters (ca $12 \mathrm{~cm}$ shell length) were placed in flow-through chambers and kept undisturbed. The flow-through rate was set at $820 \pm 20 \mathrm{ml} \mathrm{min}^{-1}$ in order to balance the pumping rate (ca $400 \mathrm{ml} \mathrm{min}^{-1}$ ) of the pearl oyster. The retention efficiency was estimated by comparing the picoplanktonic abundances at the entrance and at the exit of the chamber, using a FACScan flow cytometer.

In order to investigate the retention of protists by pearl oysters, ciliates were offered to them as potential prey, according to a protocol modified from Le Gall et al. (1997) and Pouvreau et al. (1999). The retention was studied in microcosms by comparing the evolution of protist abundances in a suspension in the presence or in the absence of a filtering (fully opened) pearl oyster. Additionally, the retention efficiency was estimated 
from the difference between the ciliate concentrations in samples withdrawn from inhalant and exhalant siphons of the oyster. To set the experimental ciliate suspension at a natural concentration, we previously investigated the ciliate densities in the Takapoto lagoon (in January 1998): 1600 cells $1^{-1}$. The grazing experiments were performed using (1) a suspension of the cultured ciliate Protocruzia sp. at a concentration of

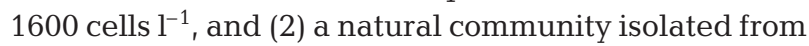
the lagoon and filtered through a $300 \mu \mathrm{m}$ mesh net in order to discard the mesozooplankton. At the start of the feeding period, 3 pearl oysters cleared of epibionts were transferred to microcosms containing 61 of protist suspension, gently homogenized to prevent sedimentation. Two duplicate experimental treatments were performed in parallel: (1) a suspension delivered to an actively filtering pearl oyster or (2) a suspension allowed to evolve without pearl oyster, and used as a control for physical sedimentation of particles.

The pearl oysters used for the experiments were on average $107 \mathrm{~mm}$ high (dorsoventral measurements according to Hind: in Gervis \& Sims 1992), with a mean soft tissue dry weight of $3.6 \pm 0.3 \mathrm{~g}$. Clearance rates and relative retention efficiencies of Pinctada margaritifera for ciliates and dinoflagellates were estimated. Clearance rate is defined as the theoretical water volume cleared of all particles per unit time (Bayne \& Widdows 1978). According to Coughlan (1969), the clearance rate was calculated from the evolution of ciliate concentration in experimental suspensions, assuming an exponential decline of retained cells:

$$
F=\left[\left(\ln C_{0}-\ln C_{t}\right) /\left(t-t_{0}\right)\right] \times \mathrm{V}
$$

where $F=$ clearance rate $\left(\mathrm{h} \mathrm{h}^{-1}\right), V=$ volume of the suspension (1), $C_{0}=$ initial concentration of the suspension (cells $\left.\mathrm{l}^{-1}\right), C_{t}=$ concentration at time $t\left(\right.$ cells $\left.\mathrm{l}^{-1}\right)$, and $\left(t-t_{0}\right)=$ time interval $(\mathrm{h})$.

Taking into account that the weight specific filtration decreased with increasing body size, the clearance rate was standardized per soft tissue dry weight of the oyster (Riisgård 1988):

\section{$F / W^{\mathrm{b}}$}

where $F$ = clearance rate $\left(\mathrm{h}^{-1}\right), W=$ oyster dry weight $(\mathrm{g})$, and $\mathrm{b}=0.61$ for P. margaritifera (Yukihira et al. 1998).

The relative retention efficiency for each ciliate taxon and for dinoflagellate orders was evaluated. It is defined as the number of a specific cell type retained per unit time, related to the initial available number of the same cell type at the beginning of the experiment. Each relative retention efficiency was calculated from the ratio of retained particles (difference of abundances at 0 and $15 \mathrm{~min}$ ), reported to the initial abundance of particles:

$$
\operatorname{Re}(\%)=100 \times\left[\left(C_{0}-C_{t}\right) / C_{0}\right]
$$

where $R e=$ relative retention efficiency, $C_{0}=$ initial particle concentration (cells ${ }^{-1}$ ), and $C_{t}=$ particle concentration (cells $\mathrm{l}^{-1}$ ) at $15 \mathrm{~min}$.

The specific contribution of ciliates to the trophic resource retained by the pearl oyster was expressed as particulate organic carbon (POC) retained per unit time and per unit of dry weight of oyster soft tissue ( $\mu \mathrm{g} \mathrm{C} \mathrm{h}^{-1} \mathrm{~g}^{-1}$ ). It was calculated as the product of the initial field carbon resource of each taxon $\left(\mu \mathrm{g} \mathrm{Cl}^{-1}\right)$ by the specific standardized clearance rate of this taxon $\left(1 \mathrm{~h}^{-1} \mathrm{~g}^{-1}\right)$.

Ingestion of ciliates by the pearl oyster. The possible ingestion of ciliates by Pinctada margaritifera was investigated by bio-labelling a Protocruzia sp. culture and detecting labelled cells in the oyster digestive tract. As scuticociliates are known to ingest cyanobacteria (Johnson et al. 1982, Caron et al. 1991), Synechococcus autofluorescence was used to perform a biolabelling of Protocruzia sp. according to Le Gall et al. (1997). The cultured Protocruzia sp. were concentrated by gentle centrifugation $\left(800 \times g, 4^{\circ} \mathrm{C}\right.$ for $\left.10 \mathrm{~min}\right)$ and washed in PBS . Simultaneously, cultured Synechococcus were sedimented by centrifugation $\left(10000 \times g, 4^{\circ} \mathrm{C}\right.$ for $30 \mathrm{~min}$ ). Ciliates which had been starved for $5 \mathrm{~h}$ were incubated for $2 \mathrm{~h}$ with their Synechococcus picoprey. The subsequent bio-labelled ciliates were sedimented, washed in PBS and resuspended in $0.2 \mu \mathrm{m}$ filtered sea water to provide the experimental 61 suspension in a natural concentration. Pearl oysters were offered bio-labelled ciliates for $15 \mathrm{~min}$. Then, oysters were dissected and their stomach contents were filtered on a black $0.2 \mu \mathrm{m}$ Nuclepore filter. The biolabelled Protocruzia sp. were detected using epifluorescence microscopy under blue ligth excitation.

\section{RESULTS}

\section{Taxonomic composition and standing stocks of picophytoplankton and heterotrophic protists in the Takapoto lagoon}

Several populations of cyanobacteria and pico/nanoeukaryotes were identified in the phytoplanktonic community from the lagoonal water. Prochlorococcus and Synechococcus constituted well-defined populations whereas the picoeukaryotes were represented by a large set of cytometric signatures, indicating a mixture of different species (Fig. 2). A pigment composition typical of cyanobacteria was confirmed by HPLC analysis. The carotenoid to chlorophyll a ( $\mathrm{chl}$ a) ratios $(\mathrm{w}: \mathrm{w})$ were 0.14 and 0.72 for $\beta$-carotene and zeaxanthin respectively. Abundance was $112.6 \times 10^{6}$ cells l $^{-1}$ 

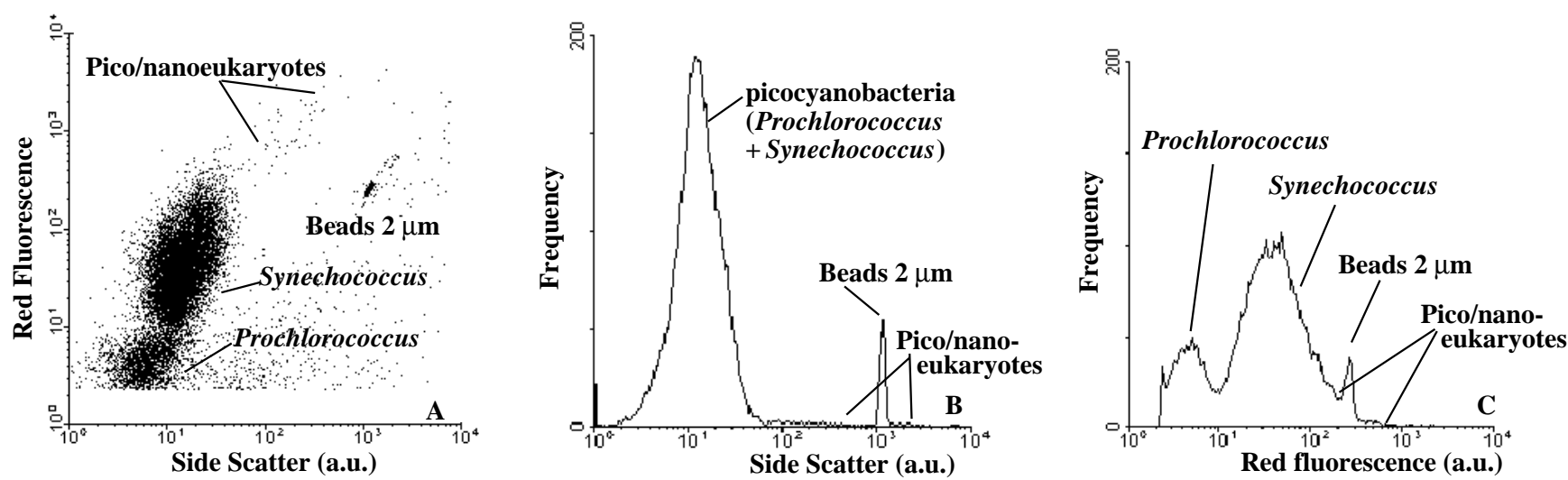

Fig. 2. Analysis of the picophytoplanktonic community of the Takapoto lagoon, using a FACSCAN flow-cytometer. (A) Red fluorescence (chlorophyll fluorescence) versus Side Scatter (size-dependent criterion). (B) Side Scatter distribution. The cyanobacteria are not discriminated, and only few picoeukaryotes are larger than $2 \mu \mathrm{m}$. (C) Red fluorescence distribution. The cyanobacteria are easily discriminated (a.u. = arbitrary units)

for Synechococcus (i.e. $94 \%$ of the autotrophic picoplankton), $5.6 \times 10^{6}$ cells l$^{-1}(4.7 \%)$ for Prochlorococcus

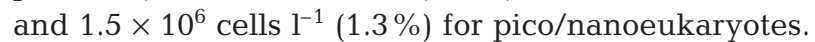
In terms of carbon, the contribution of the main pico-

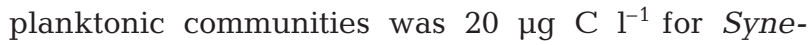
chococcus and $0.4 \mathrm{\mu g} \mathrm{Cl}^{-1}$ for Prochlorococcus. In spite of their low abundance, the heterogeneous community of pico/nanoeukaryotes might account for an available $\mathrm{C}$ resource, due to their rather high biovolume and carbon content compared to cyanobacteria.

In the Takapoto lagoon, in February 1998, 7 orders of protists were identified (Table 1). The ciliates belonged to 4 orders, mainly represented by Choreotrichida (Codonella sp. and Favella sp.), Oligotrichida (Strombidium sp.) and Pleurostomatida (Amphileptus spp.). Dinoflagellates were represented by 3 orders
(Peridiniales, Gymnodiniales and Prorocentrales), dominated by Protoperidinium sp. and Gymnodinium sp. They were mainly heterotrophic, as shown by observation using an epifluorescence microscopy. The length of the identified ciliates ranged from 30 (Protocruzia sp.) to $136 \mu \mathrm{m}$ (Favella sp.). The Choreotrichida were characterized by a high cell carbon content, ranging from ca 14000 (Amphorides sp.) to ca 55000 pg C cell ${ }^{-1}$ (Favella sp.). The cell carbon content of Oligotrichida and Pleurostomatida was lower, except for large genera such as Laboea sp. (49300 pg C cell ${ }^{-1}$ ) and Amphileptus sp. (ca $29000 \mathrm{pg} \mathrm{C}$ cell $^{-1}$ ). The dinoflagellates were smaller in length (18 to $83 \mu \mathrm{m})$ and their carbon content (ca 150 to $4000 \mathrm{pg} \mathrm{C} \mathrm{cell}^{-1}$ ) was significantly lower than those of ciliates.

Table 1. Taxonomic composition, size, biovolume and cell carbon content of the protist community in the Takapoto lagoon, in February 1998

\begin{tabular}{|c|c|c|c|c|c|c|}
\hline Order & Family & Taxon & $\begin{array}{l}\text { Length } \\
(\mu \mathrm{m})\end{array}$ & $\begin{array}{l}\text { Width } \\
(\mu \mathrm{m})\end{array}$ & $\begin{array}{l}\text { Biovolume } \\
\left(\times 10^{3} \mu^{3}\right)\end{array}$ & $\begin{array}{l}\text { Carbon per cell } \\
\left(\text { pg C cell }{ }^{-1}\right)\end{array}$ \\
\hline Choreotrichida & $\begin{array}{l}\text { Codonellidae } \\
\text { Tintinnidae } \\
\text { Ptychocylididae }\end{array}$ & $\begin{array}{l}\text { Codonella sp. } \\
\text { Amphorides sp. } \\
\text { Favella sp. }\end{array}$ & $\begin{array}{r}70 \\
116 \\
136\end{array}$ & $\begin{array}{l}44 \\
27 \\
58\end{array}$ & $\begin{array}{r}163 \\
81 \\
325\end{array}$ & $\begin{array}{l}27710 \\
13770 \\
55250\end{array}$ \\
\hline Oligotrichida & Strombiidae & $\begin{array}{l}\text { Laboea sp. } \\
\text { Strombidium sp. }\end{array}$ & $\begin{array}{r}132 \\
50\end{array}$ & $\begin{array}{l}75 \\
30\end{array}$ & $\begin{array}{r}290 \\
17\end{array}$ & $\begin{array}{r}49300 \\
2890\end{array}$ \\
\hline Pleurostomatida & Amphileptidae & $\begin{array}{l}\text { Amphileptus sp. } 1 \\
\text { Amphileptus sp. } 2\end{array}$ & $\begin{array}{r}136 \\
55\end{array}$ & $\begin{array}{l}49 \\
21\end{array}$ & $\begin{array}{l}170 \\
6.3\end{array}$ & $\begin{array}{r}28900 \\
1071\end{array}$ \\
\hline Scuticociliatida & Protocruziidae & Protocruzia sp. & 30 & 15 & 2.6 & 442 \\
\hline Amaebida & & & 61 & 41 & 54 & 9180 \\
\hline Gymnodiniales & Gymnodiniaceae & Gymnodinium sp. & 18 & 12 & 1.3 & 231 \\
\hline Prorocentrales & Prorocentraceae & Prorocentrum sp. & 40 & 25 & 13 & 2224 \\
\hline Peridiniales & $\begin{array}{l}\text { Peridiniaceae } \\
\text { Oxytoxaceae }\end{array}$ & $\begin{array}{l}\text { Protoperidinium sp. } \\
\text { Oxytoxum sp. }\end{array}$ & $\begin{array}{l}83 \\
30\end{array}$ & $\begin{array}{r}35 \\
8\end{array}$ & $\begin{array}{r}24 \\
1\end{array}$ & $\begin{array}{r}4151 \\
171\end{array}$ \\
\hline
\end{tabular}



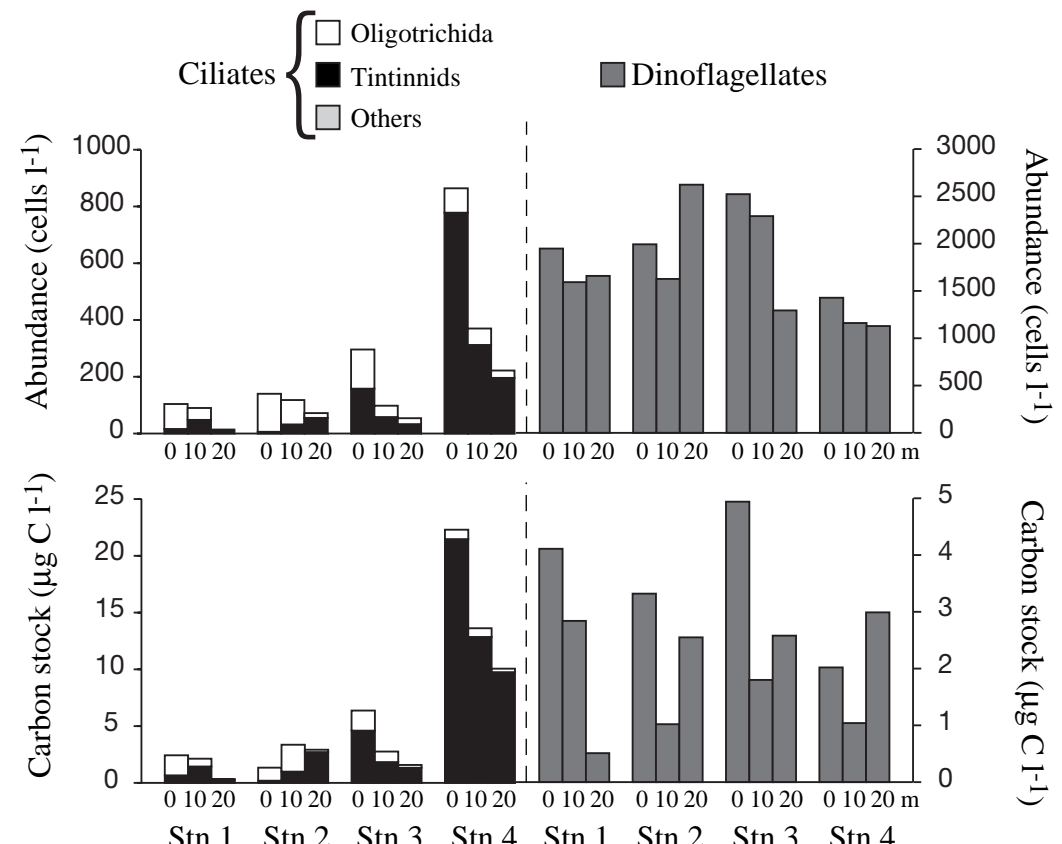

Fig. 3. Spatial distribution of abundance and carbon stock of ciliates (oligotrichs and tintinnids) and dinoflagellates, at 4 stations and 3 depths (data collected on 2 February $1998,08: 00$ to $10: 00$ h) gellates respectively. The maximal values were observed in surficial waters, at Stn 4 for ciliates and at Stn 3 for dinoflagellates. On the whole, the mean carbon biomass estimated from the 2 sampling days was evaluated as $6 \mu \mathrm{g} \mathrm{C} \mathrm{l}^{-1}$ for ciliates and $2 \mu \mathrm{g} \mathrm{C} \mathrm{l}^{-1}$ for dinoflagellates.

\section{Pearl oyster grazing on heterotrophic protists and picoplankton}

In oyster grazing experiments, on a Protocruzia sp. suspension, the abundance of the ciliate decreased rapidly in the presence of a filtering bivalve, whereas it remained almost constant in the control trays (Fig. 5). Simultaneous withdrawal of water aliquots from the exhalant versus inhalant siphon of the bivalve showed that ciliate abundance

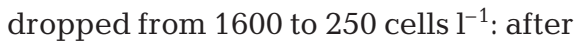
a single passage through the gill, ca $85 \%$ of the ciliates were retained by the bivalve.

The total protist abundance ranged from ca 500 to 3000 cells $\mathrm{l}^{-1}$ (mean \pm SD: $1595 \pm 607$ cells $\mathrm{l}^{-1}, \mathrm{n}=24$ ). Dinoflagellates were always more numerous (ca 350 to 2500 cells $1^{-1}$ ) than ciliates (15 to 850 cells $\mathrm{l}^{-1}$ ). The protist abundance was highly variable according to the sampling site and depth (Fig. 3). Ciliates were mostly abundant at Stn 4, especially in surface waters, where, in contrast, the abundance of the dinoflagellates was the lowest. Among ciliates, tintinnids (i.e. suborder Tintinnina: Codonellidae, Tintinnidae, Ptychocylididae, ...) and Oligotrichida were similarly abundant $\left(102 \pm 161\right.$ vs $86 \pm 64$ cells $\left.1^{-1}\right)$. During the diel cycle (Fig. 4), the maximal abundance of ciliates (ca 300 cells $\mathrm{l}^{-1}$ ) was observed in surface waters during the day. The dinoflagellates reached a maximal value of ca 2000 cells $1^{-1}$ at $5 \mathrm{~m}$ depth at 00:00 h.

The planktonic carbon resource was estimated from the carbon cell content of each protist taxon multiplied by its specific field abundance. The carbon biomass of protists on 2 February 1998 (Fig. 3) ranged from 0.2 to 24 and from 0.5 to $5 \mu \mathrm{g} \mathrm{C}^{-1}$ for ciliates and dinofla-

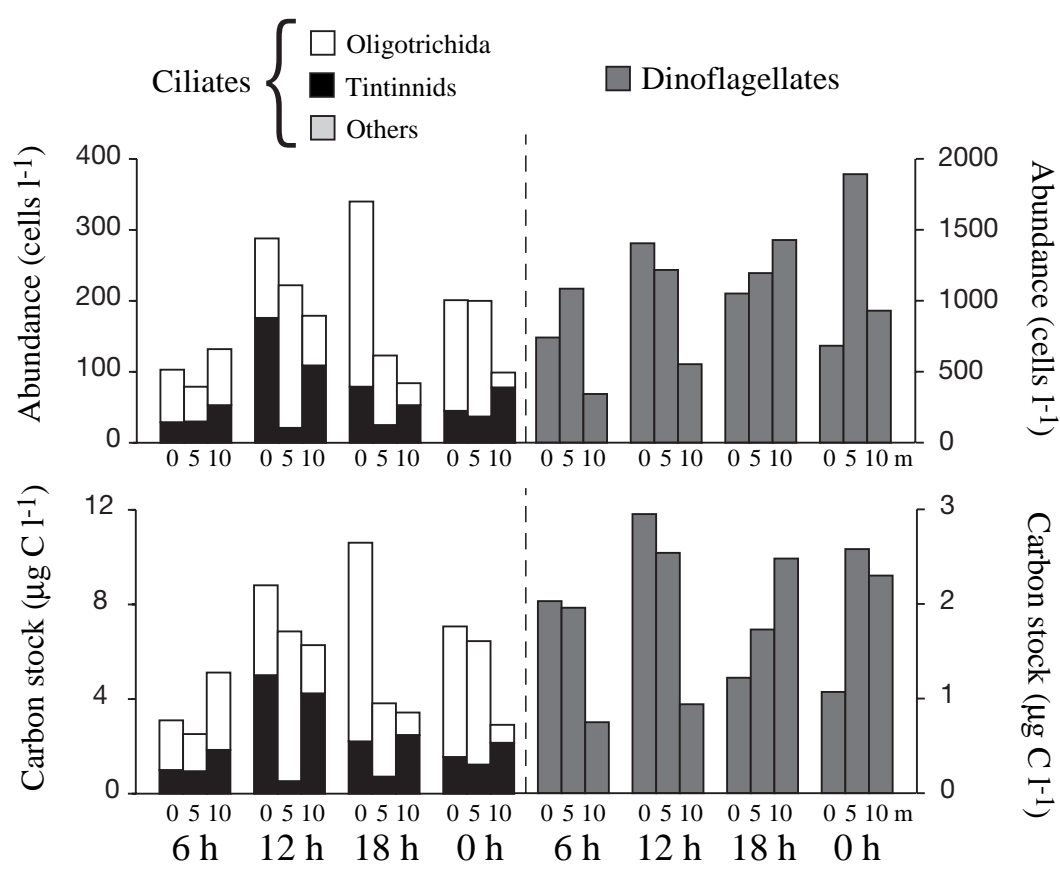

Fig. 4. Diel variations of abundance and carbon stock of ciliates (oligotrichs and tintinnids) and dinoflagellates, at Stn 4 and at 3 depths (data collected on 4 February 1998) 


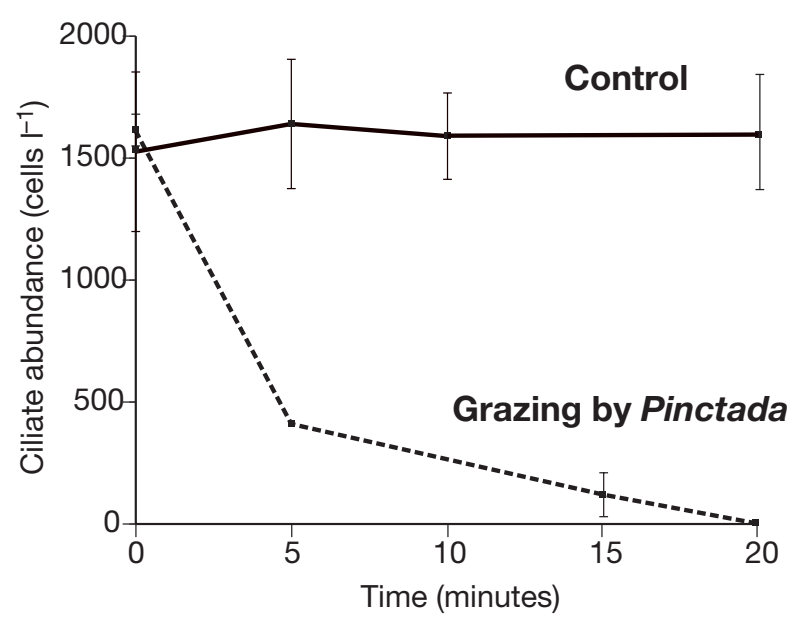

Fig. 5. Pinctada margaritifera. Retention of the cultured ciliate Protocruzia sp. by the pearl oyster

trays drastically decreased within 15 min from 243 to 24 cells $\mathrm{l}^{-1}$ for ciliates and from 468 to 7 cells $\mathrm{l}^{-1}$ for dinoflagellates (Fig. 6). On the contrary, protist abundance remained constant in the control trays. The relative retention efficiency, estimated from abundance decrease of the protist community, was $92 \%$ for large Laboea sp. (132 $\mu \mathrm{m}$ length), $97 \%$ for Amphileptus sp. 1 (136 $\mu \mathrm{m}$ length) and 99\% for dinoflagellates (Table 2).

The clearance rate evaluated for oysters grazing on Protocruzia sp. suspensions was $69 \mathrm{l} \mathrm{h}^{-1}$ (ca $30 \mathrm{l} \mathrm{h}^{-1} \mathrm{~g}^{-1}$ ). When measured from particle retention kinetics on the lagoonal community, the clearance rate was estimated
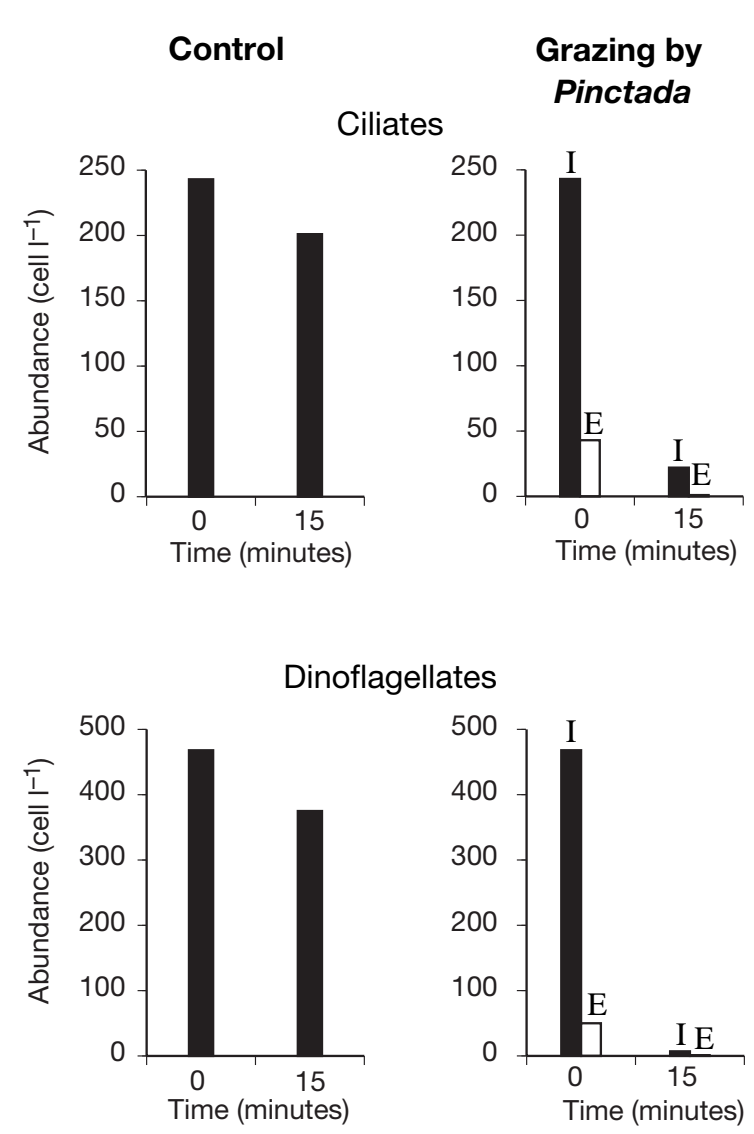

Fig. 6. Pinctada margaritifera. Retention of ciliates and dinoflagellates from the lagoonal protist community by the pearl oyster ( $\mathrm{I}=$ inhaling current, $\mathrm{E}=$ exhaling current)

Table 2. Pinctada margaritifera. Grazing by the pearl oyster on a lagoonal ciliate and dinoflagellate community: potential carbon resource in the lagoon and carbon resource retained by the oysters (per unit of time and dry weight; \% is the contribution of each protist taxon to the total retained resource)

\begin{tabular}{|c|c|c|c|c|c|c|c|}
\hline Taxon (length/width, $\mu \mathrm{m}$ ) & $\begin{array}{l}\text { Initial protist } \\
\text { abundance } \\
\left(\text { cell l }^{-1}\right)\end{array}$ & $\begin{array}{c}\text { Carbon per } \\
\text { cell } \\
\left(\mathrm{ng} \mathrm{C} \mathrm{cell}{ }^{-1}\right)\end{array}$ & $\begin{array}{c}\text { Potential C } \\
\text { resource } \\
\left(\mathrm{ng} \mathrm{C} \mathrm{l}^{-1}\right)\end{array}$ & $\begin{array}{l}\text { Clearance } \\
\text { rate } \\
\left(\mathrm{l} \mathrm{h}^{-1} \mathrm{~g}^{-1}\right)\end{array}$ & $\begin{array}{c}\text { Retained } \\
\text { resource } \\
\left(\mu \mathrm{C}^{-1} \mathrm{~g}^{-1}\right)\end{array}$ & $\%$ & $\begin{array}{c}\text { Retention } \\
\text { efficiency } \\
(\%)\end{array}$ \\
\hline \multicolumn{8}{|l|}{ Choreotrichida } \\
\hline Codonella sp. (70/44) & 36 & 27.7 & 998 & 20 & 19.8 & 13.0 & 92 \\
\hline Amphorides sp. (116/27) & 12 & 13.8 & 165 & 14 & 2.3 & 1.5 & 83 \\
\hline Favella sp. (146/58) & 5 & 55.3 & 276 & 12 & 3.3 & 2.2 & 78 \\
\hline \multicolumn{8}{|l|}{ Oligotrichida } \\
\hline Laboea sp. (132/49) & 12 & 49.3 & 592 & 20 & 11.8 & 7.7 & 92 \\
\hline Strombidium sp. $(50 / 30)$ & 36 & 2.9 & 104 & 20 & 2.1 & 1.4 & 92 \\
\hline \multicolumn{8}{|l|}{ Pleurostomatida } \\
\hline Amphileptus sp. 1 (136/49) & 59 & 28.9 & 1705 & 27 & 46.2 & 30.3 & 97 \\
\hline Amphileptus sp. $2(55 / 21)$ & 33 & 1.1 & 35 & 10 & 0.3 & 0.2 & 71 \\
\hline $\begin{array}{l}\text { Dinoflagellates } \\
\text { (mainly Protoperidinium) }\end{array}$ & 468 & 4.1 & 1941 & 33 & 64.1 & 42.1 & 99 \\
\hline \multicolumn{8}{|l|}{ Total } \\
\hline Ciliates & 193 & & 3875 & & 86.8 & 56.9 & \\
\hline Dinoflagellates & 468 & & 1941 & & 64.1 & 42.1 & \\
\hline
\end{tabular}


as ca $15 \mathrm{l} \mathrm{h}^{-1} \mathrm{~g}^{-1}$ for Choreotrichida and $20 \mathrm{l} \mathrm{h}^{-1} \mathrm{~g}^{-1}$ for Oligotrichida. To estimate the ciliate and dinoflagellate energetic resource retained by the pearl oyster, the amount of cleared $C$ relative to each planktonic taxon was calculated (Table 2). In our experimental suspension, ciliate and dinoflagellate protists from lagoon water represented an initial $\mathrm{C}$ resource of ca 4 and $2 \mu \mathrm{g} \mathrm{C} \mathrm{l}^{-1}$ respectively. The retention depended upon the protist taxon involved: dinoflagellates were more efficiently retained than Pleurostomatida, Choreotrichida and Oligotrichida ciliates. The amount of carbon resource retained from protists reached $87 \mu \mathrm{g} \mathrm{C} \mathrm{h} \mathrm{h}^{-1} \mathrm{~g}^{-1}$ for ciliates and $64 \mu \mathrm{g} \mathrm{C} \mathrm{h} \mathrm{h}^{-1} \mathrm{~g}^{-1}$ for dinoflagellates. Though ciliates were less efficiently retained, their contribution to the food resources of oysters was higher, due to their high biovolume.

To be sure that retained ciliates were ingested, oysters were offered bio-labelled Protocruzia sp. suspensions. The autofluorescent labelling was observed in high densities in the digestive tract contents of Pinctada margaritifera, showing the ingestion of protists by the pearl oyster. Moreover, protists were identified in the stomach contents of 3 pearl oysters which had been left in the lagoon for 1 night: ciliates (mainly Codonella sp.) and dinoflagellates (mainly Protoperidinium sp. and Prorocentrum sp.).

In contrast, experiments investigating the retention of picophytoplankton by pearl oysters showed that phytoplankton $<2 \mu \mathrm{m}$ was not efficiently retained by the gills of the bivalves. The retention efficiency was $0 \%$ for Prochlorococcus and $0.2 \%$ for Synechococcus. Pico/nanoeukaryotes, from 1 to $3 \mu \mathrm{m}$ in diameter, were retained by the pearl oyster with an efficiency of ca $30 \%$. However, due to their low abundance, pico/ nanoeukaryotes probably only represent a weak carbon resource retained for the bivalve.

\section{Energy transfer from picoplanktonic prey to ciliate protists}

In order to assess the potential role of protists to act as a link, we evaluated the ability of the scuticociliate Protocruzia sp. to grow on various auto- and heterotrophic picoplanktonic cells, and estimated its growth rate and growth efficiency.

The growth kinetics of the ciliate Protocruzia sp. showed 3 successive phases: a latency period with a slow increase in ciliate number until $18 \mathrm{~h}$, an exponential phase, in which the ciliate abundance rapidly increased from 18 to $24 \mathrm{~h}$, and a stationary phase after $42 \mathrm{~h}$ of culture.

The in vitro study of the ciliate growth was performed during the exponential growth phase, in relation to the type of picoprey (initial concentration simi- lar for each prey type: $5 \times 10^{8}$ cells $\mathrm{l}^{-1}$ ). The ciliate abundance at the end of the exponential growth phase was minimal with bacterial strains BS1 or BS2 and slightly higher with the Synechococcus $\mathrm{ROSCO}_{4}$ (Fig. 7).

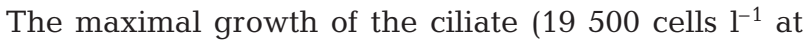
$24 \mathrm{~h}$ ) was obtained in presence of the Synechococcus strain TAK 9802. The specific growth rate of Protocruzia sp. was equal to $0.19 \mathrm{~h}^{-1}$. The generation time of $4 \mathrm{~h}$ means that this ciliate multiplies 6 times a day. Its gross growth efficiency was estimated as $41 \%$.

\section{DISCUSSION}

Tropical atoll lagoons have been described as biological oases, isolated in an extremely oligotrophic ocean (Hatcher 1997). In the Tuamotu Archipelago, farming of the pearl oyster has rapidly increased because of the economic impact of black pearl production. Though originally benthic, Pinctada margaritifera is now reared on suspended ropes and the resulting interactions with pelagic communities raise questions about the ability of planktonic food webs to sustain such an increase in animal production. In atoll lagoons, the primary production is mainly achieved by picophytoplankton (Charpy et al. 1992, Charpy 1996, Charpy \& Blanchot 1996, 1998), whereas the biomass is dominated by low-producing bacteria (Torréton \& Dufour 1996). As both picoplankters are in a size range unavailable to oysters (Jonquières et al. 1994, Dufour \& Torréton 1995, Pouvreau et al. 1999), it was hypothesized that phagotrophic protists may act as an inter-

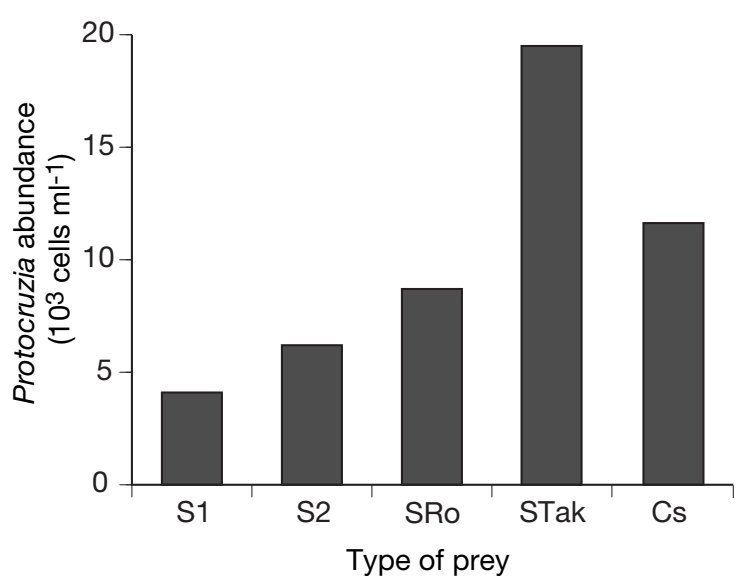

Fig. 7. Abundance of the ciliate Protocruzia at the end of the exponential growth phase $(24 \mathrm{~h})$, in relation to the nature of the offered prey: 2 bacterial strains isolated from the Takapoto lagoon (BS1 and BS2), Synechococcus $\mathrm{ROSCO}_{4}$ (SRo) isolated from the Atlantic ocean and a Synechococcus (STak) strain isolated from Takapoto lagoon. Initial concentration of prey $=10^{8}{\text { cells } l^{-1}}^{-1}$ 
mediate between the dominant picoproduction and bivalves. Such a trophic link was shown for Crassostrea gigas in Atlantic ponds (Le Gall et al. 1997, Dupuy et al. 1999).

\section{Planktonic heterotrophic protists as an energy resource in the Takapoto lagoon}

In coral reef ecosystems, the planktonic food web remains poorly described, as coral reefs were considered to be dominated by benthic communities (e.g. Sournia 1977, Kinsey 1985). However, in atoll lagoons, where coral patches are scarce and water often deep, planktonic productivity can exceed that of benthos (Charpy-Roubaud 1988, Furnas 1988).

In February 1998, the $>35 \mu \mathrm{m}$ protist community of the Takapoto lagoon included ciliates and heterotrophic dinoflagellates. A similar taxonomic composition was described by Sakka (1999) in the same lagoon. During our study, heterotrophic dinoflagellates dominated in terms of cell numbers, with a rather homogeneous spatial distribution. Ciliates were less abundant than dinoflagellates and showed variable distribution according to the sampling site. Additionally, ciliate density increased during the day; Sakka (1999) observed a decrease in the $>35 \mu \mathrm{m}$ protists at night and related this to predation by zooplankton, which migrates to the surface at night (Renon 1977). The abundance of heterotrophic dinoflagellates we reported in the Takapoto lagoon was 6 -fold lower than in Tikehau Atoll, where it reached 25000 cells l $^{-1}$ (González et al. 1998). In our study, tintinnids were as abundant as

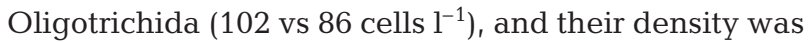
much higher than those reported in Tikehau Atoll: 5 to 30 cells $1^{-1}$ (Blanchot et al. 1989). However, our data are too scarce to determine whether these low heterotrophic dinoflagellate densities and high tintinnid abundances are a permanent feature of the planktonic community of the Takapoto lagoon, related to the particular morphology of this closed atoll, or just a transient increase, as a consequence of particular meteorological conditions due to the tropical storm Veli.

During our study, ciliates were represented by largesized species with high cellular carbon contents. Codonella sp., a very abundant ciliate, accounted for $28000 \mathrm{pg} \mathrm{C}$ cell $^{-1}$, and even the small sized ciliate Strombidium sp. contained 2900 pg C cell ${ }^{-1}$ (a value close to $3100 \mathrm{pg} \mathrm{C}$ cell $^{-1}$ previously reported by Stoecker \& Egloff [1987] for Strombidium sp.). As a consequence, ciliates accounted for a high carbon biomass in the field (ca $6 \mu \mathrm{g} \mathrm{C}^{-1}$ ) compared to that of the

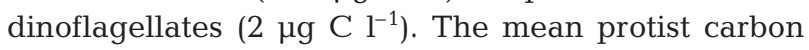
biomass was $8 \mu \mathrm{g} \mathrm{Cl}^{-1}$, which is lower than the value of $20 \mu \mathrm{g} \mathrm{C}^{-1}$ reported for the $>35 \mu \mathrm{m}$ protists in April
1997 in the same lagoon (Sakka 1999). These C resource values can be compared to the autotrophic carbon biomass. From chl a concentrations, phytoplankton $>2 \mu \mathrm{m}$, i.e. potentially available to pearl oysters,

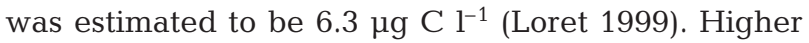
values of carbon were reported for phytoplankton $>3 \mu \mathrm{m}: 12.5$ (Charpy \& Blanchot 1998) and $13 \mu \mathrm{g} \mathrm{C} \mathrm{l}^{-1}$ (Sakka 1999). Hence, in the size range available to oysters, the autotrophic and heterotrophic carbon biomasses are in the same order of magnitude in Takapoto Atoll: 6 to 13 and 8 to $20 \mu \mathrm{g} \mathrm{Cl}^{-1}$ respectively.

\section{Contribution of hetero/mixotrophic protists to the pearl oyster diet}

Grazing experiments showed that Pinctada margaritifera does not efficiently retain picoparticles, either Synechococcus (this study), free-living bacteria $0.4 \mu \mathrm{m}$ in diameter (Dufour \& Torréton 1995) or the $1 \mu \mathrm{m}$ cyanobacterium Aphanocapsa (Pouvreau et al. 1999). Conversely, the pearl oyster actively grazed either cultured scuticociliates from an experimental suspension in a natural concentration, or ciliates and dinoflagellates from the planktonic lagoonal community. The clearance rates (i.e. the water volume entirely cleared from particles by oyster per unit time) varied from $15 \mathrm{l} \mathrm{h}^{-1} \mathrm{~g}^{-1}$ for Choreotrichida ciliates to $33 \mathrm{l} \mathrm{h}^{-1} \mathrm{~g}^{-1}$ for dinoflagellates. Those high values are in the same range as clearance rates of 24 and $26 \mathrm{l} \mathrm{h}^{-1} \mathrm{~g}^{-1}$ performed by Pinctada margaritifera fed an Isochrysis galbana diet (Yukihira et al. 1998, Pouvreau et al. 1999). Similarly, the relative retention efficiency, evaluated for each protist taxon of the natural community, ranged from 85 to $99 \%$, close to the previously reported value of $98 \%$ for a diet of $I$. galbana (Pouvreau et al. 1999). When compared to other bivalves, the pearl oyster, when grazing on heterotrophic protists, exhibits a high retention efficiency (>90\%), similar to that of the oyster Crassostrea gigas (90\%) (Le Gall et al. 1997, Dupuy et al. 1999). In contrast, the Atlantic bivalves Geukensia demissa and Mytilus edulis are less efficient when grazing on nanoflagellates, as their retention efficiency is only 60 to $70 \%$ (Kreeger \& Newell 1996). The fact that the pearl oyster retains $I$. galbana and phagotrophic protists with the same efficiency indicates that the autotrophic or heterotrophic nature of the prey does not influence retention by the oyster. However, despite this variety of available food sources, it was recently demonstrated that pearl oysters exert selective feeding, especially on cryptophytes (Loret et al. 2000).

The ingestion of ciliate protists by the pearl oyster was demonstrated in this study by the observation of labelled scuticociliates in their stomach contents. Pro- 
tists have been previously identified in the stomach contents of Pinctada margaritifera from Polynesia (Marchal 1993, Hautefeuille 1994, Loret 1995) and from the Red Sea (Nasr 1984). Similarly, protists were observed in the gut contents of Pinctada fucata in India (Chellam 1983) and of Ostrea edulis on the Atlantic coast (Paulmier 1972).

In conclusion, the maximal clearance rates of Pinctada margaritifera allows, in Takapoto Atoll, the retention of an important trophic resource from hetero/ mixotrophic protists: $85 \mu \mathrm{g} \mathrm{C} \mathrm{h} \mathrm{h}^{-1} \mathrm{~g}^{-1}$ from ciliates and $65 \mu \mathrm{g} \mathrm{C} \mathrm{h} \mathrm{h}^{-1} \mathrm{~g}^{-1}$ from dinoflagellates.

\section{Protists as a trophic link between picoplankton and oysters}

The importance of protists in energy transfer within marine food webs was mainly investigated for pelagic consumers, especially zooplankton (Berk et al. 1977, Porter et al. 1979) and was only recently considered for benthic suspension-feeders. The oyster Crassostrea gigas retains a bacterivorous ciliate Uronema (Le Gall et al. 1997) and a natural hetero/mixotrophic protist community (Dupuy et al. 1999). Similarly, it was shown that the bivalves Geukensia demissa and Mytilus edulis feed on heterotrophic nanoflagellates (Kreeger \& Newell 1996). Moreover, carbon fluxes in the planktonic network of the Takapoto lagoon have been quantified through modelling, using an inverse analysis technique. Though a first model, built from data collected between 1990 and 1994, awarded a minor role to protists (Niquil et al. 1998), a second model, based on data collected from 1996 to 1997, showed that protozooplankton in the Takapoto lagoon was an obligate pathway in carbon fluxes (Niquil 1998).

As our experiments had shown that pearl oysters efficiently grazed on ciliate protists but they could not feed on picophytoplankton, the importance of the carbon flux from picoprey to phagotrophic protists was studied. The growth of the cultured ciliate Protocruzia sp. evidenced that the cyanobacteria Synechococcus TAK was the most efficient prey to promote its development. Although the ciliate was not abundant in the natural community of protists at the time of our study, it can however be considered as a picoplanktonivorous protist model: its high growth rate $\left(0.19 \mathrm{~h}^{-1}\right)$ and short generation time (ca $4 \mathrm{~h}$ ) are close to those described for other species of scuticociliates (Hamilton \& Preslan 1969) and tintinnids (Verity 1986). Additionally, the gross growth efficiency of Protocruzia sp. fed with a Synechococcus TAK diet was ca $50 \%$. Such high efficiency in the transfer of organic biomasses has been previously reported in the scuticociliate Uronema (Sherr et al. 1987), in Strombidium (Fenchel \& Jonsson 1988) and in tintinnids (Heinbokel 1978). If this holds for other phagotrophic protists from the Takapoto Atoll lagoon, they may channel a large part of the cyanobacterial picoproduction towards the pearl oyster Pinctada margaritifera and thus allow this small-sized primary production to be indirectly available to the bivalve.

Acknowledgements. This research was carried out within the framework of the Programme Général de Recherche sur la Nacre (PGRN). It was partly supported by the European Community program MAST (Contract number MAS3 CT97 0149, DOMTOX). We express our gratitude to the Director of the Service des Ressources Marines (SRM) in Takapoto Atoll, G. Haumani, and his team for efficient assistance in the field. We also thank Dr Alain Bodoy, and his team, from the 'Nacre' Laboratory of IFREMER/COP (Tahiti), Dr Jean Pages (IRDTahiti) for lending sampling and filtering material, Mr JeanPierre Rochette (SRM) for his assistance in the field, and $\mathrm{Mr}$ Frank Lagarde for his help. We thank Ghislaine Fryd (Université Paris-Orsay) for protist identification, Sandrine Boulben (Roscoff) for the FACScan analysis and Martine Bréret (CREMA) for maintenance of lagoonal ciliates and cyanobacteria in cultures. We also thank the 5 reviewers for their helpful comments.

\section{LITERATURE CITED}

Azam F, Fenchel T, Field JG, Gray JS, Meyer-Reil LA, Thingstad F (1983) The ecological role of water-column microbes in the sea. Mar Ecol Prog Ser 10:257-263

Bayne BL, Widdows J (1978) The physiological ecology of two populations of Mytilus edulis L. Oecologia 37:137-162

Berk SG, Brownlee DC, Heinle DR, Kling HJ, Colwell RR (1977) Ciliates as a food source for marine planktonic copepods. Microb Ecol 4:27-40

Blanchot J, Rodier M (1996) Picophytoplankton abundance and biomass in the western tropical Pacific Ocean during the 1992 El Niño year: results from flow cytometry. DeepSea Res I 43:877-895

Blanchot J, Charpy L, Le Borgne R (1989) Size composition of particulate organic matter in the lagoon of Tikehau Atoll (Tuamotu archipelago). Mar Biol 102:329-339

Caron DA, Lim EL, Miceli G, Waterbury JB, Valois FW (1991) Grazing and utilization of chroococcoid cyanobacteria and heterotrophic bacteria by protozoa in laboratory cultures and a coastal plankton community. Mar Ecol Prog Ser 76: 205-217

Charpy L (1996) Phytoplankton biomass and production in two Tuamotu Atoll lagoons (French Polynesia). Mar Ecol Prog Ser 145:133-142

Charpy L, Blanchot J (1996) Prochlorococcus contribution to phytoplankton biomass and production of Takapoto Atoll (Tuamotu archipelago). C R Acad Sci Paris 319:131-137

Charpy L, Blanchot J (1998) Photosynthetic picoplankton in French Polynesian atoll lagoons: estimation of taxa contribution to biomass and production by flow cytometry. Mar Ecol Prog Ser 162:57-70

Charpy L, Blanchot J, Lo L (1992) Contribution des cyanobactéries (Synechococcus spp.) à la production phytoplanctonique dans un lagon d'atoll fermé (Takapoto, Tuamotu, Polynésie française). C R Acad Sci Paris 314:395-401

Charpy-Roubaud CJ (1988) Production primaire des fonds meubles du lagon de Tikehau (Atoll des Tuamotu, Poly- 
nésie française). Oceanol Acta 11(3):241-248

Chellam A (1983) Study on the stomach contents of pearl oyster Pinctada fucata (Gould) with reference to the inclusion of bivalve eggs and larvae. Proc Symp Coastal Aquaculture 2:604-607

Coughlan J (1969) The estimation of filtering rate from the clearance of suspensions. Mar Biol 2:356-358

Dufour P, Torréton JP (1995) Rétention des bactéries par l'huître perlière Pinctada margaritifera. Programme Général de Recherche sur la Nacre (PGRN) Action de Recherche no. 19-Nutrition. Rapport Intermédiaire. ORSTOM, Papeete

Dupuy C, Le Gall S, Hartmann HJ, Bréret M (1999) Retention of ciliates and flagellates by the oyster Crassostrea gigas in French Atlantic coastal ponds: protists as a trophic link between bacterioplankton and benthic suspension-feeders. Mar Ecol Prog Ser 177:165-175

Fenchel T, Jonsson PR (1988) The functional biology of Strombidium sulcatum, a marine oligotrich ciliate (Ciliophora, Oligotrichina). Mar Ecol Prog Ser 48:1-15

Furnas MJ (1988) The behavior of nutrients in tropical aquatic ecosystems. In: Connel DW, Hawker DW (eds) Pollution in tropical aquatic ecosystems, Chap 2. CRC Press, London, p 29-65

Gervis MH, Sims NA (1992) The biology and culture of pearl oysters (Bivalvia: Pteriidae). ICLARM Stud Rev 21

González JM, Torréton JP, Dufour P, Charpy L (1998) Temporal and spatial dynamics of the pelagic microbial food web in an atoll lagoon. Aquat Microb Ecol 16:53-64

Guillard RRL, Ryther JH (1962) Studies of marine planktonic diatoms. I Cyclotella nana Hustedt, and Detonula confervacea (Cleve) Gran. Can J Microbiol 8:229-239

Haas LW (1982) Improved epifluorescence microscopy for observing planktonic micro-organisms. Ann Inst Océanogr 58:261-266

Hamilton RD, Preslan JE (1969) Cultural characteristics of a pelagic marine hymenostome ciliate, Uronema sp. J Exp Mar Biol Ecol 4:90-99

Hatcher BG (1997) Organic production and decomposition. In: Birkeland C (ed) Life and death of coral reefs. Chapman and Hall, New York, p 140-174

Hautefeuille F (1994) Aspects économiques et techniques de la perliculture en Polynésie française. Contribution à l'étude de l'alimentation de l'huître perlière Pinctada margaritifera. Rapport de stage, Institut Supérieur Technique d'Outre Mer, Paris

Hawkins AJS, Smith RFM, Tan SH, Yasin ZB (1998) Suspension-feeding behaviour in tropical bivalve molluscs: Perna viridis, Crassostrea belcheri, Crassostrea iradelei, Saccostrea cucculata and Pinctada margaritifera. Mar Ecol Prog Ser 166:173-185

Heinbokel JF (1978) Studies on the functional role of tintinnids in the Southern California Bight. I. Grazing and growth rates in laboratory cultures. Mar Biol 47:177-189

Herdman WA (1903) Observations and experiments on the life-history and habits of the pearl oyster. Report to the Government of Ceylon on the pearl oyster fisheries of the Gulf of Manaar, Vol 1. The Royal Society, London, p 1-307

Johnson PW, Huai-Shu X, Sieburth JMcN (1982) The utilization of chroococcoid cyanobacteria by marine zooplankters but not by calanoid copepods. Ann Inst Océanogr 58: 297-308

Jonquières $\mathrm{G}$, Buestel $\mathrm{D}$, Blanchot $\mathrm{J}$, Pouvreau $\mathrm{S}$, Bougrier $\mathrm{S}$, Geairon P (1994) Etude de la rétention du phytoplancton par l'huître perlière Pinctada margaritifera. Centre Océanologique du Pacifique. Programme Général de Recherche sur la Nacre (PGRN) Action de Recherche no.
19 - Nutrition. Rapport Intermédiaire, IFREMER, Vairao Kinsey WD (1985) Metabolism, calcification and carbon production. Proc 5th Int Coral Reef Congr, Tahiti 4:515-526

Kreeger DA, Newell RIE (1996) Ingestion and assimilation of carbon from cellulolytic bacteria and heterotrophic flagellates by the mussels Geukensia demissa and Mytilus edulis (Bivalvia, Mollusca). Aquat Microb Ecol 11:205-214

Leakey RJG, Burkill PH, Sleigh MA (1994) A comparison of fixatives for the estimation of abundance and biovolume of marine planktonic ciliate populations. J Plankton Res 16: 375-389

Le Gall S, Bel Hassen M, Le Gall P (1997) Ingestion of a bacterivorous ciliate by the oyster Crassostrea gigas: protozoa as a trophic link between picoplankton and benthic suspension-feeders. Mar Ecol Prog Ser 152:301-306

Loret P (1995) Composition du plancton de Takapoto et régime alimentaire de l'huître perlière Pinctada margaritifera. Rapport de Diplôme d'Etudes Approfondies, Université Française du Pacifique, Papeete

Loret P (1999) Le régime alimentaire et la sélection des particules chez l'huître perlière Pinctada margaritifera dans le lagon de Takapoto (Tuamotu, Polynésie française). Thèse de l'Université de la Polynésie française, Papeete

Loret P, Pastoureaud A, Bacher C, Delesalle B (2000) Phytoplankton composition and selective feeding of the pearl oyster Pinctada margaritifera in the Takapoto lagoon (Tuamotu Archipelago, French Polynesia): in situ study using optical microscopy and HPLC pigment analysis. Mar Ecol Prog Ser 199:55-67

Mansour K, Gabal MN (1980) Food and feeding of the pearl oysters and some other lamellibranchs in the Red Sea. Proc Egypt Acad Sci 33:209-216

Marchal G (1993) L'huître perlière, étude du contenu stomacal. Rapport de stage, Institut Supérieur Technique d'Outre Mer. Paris

Nasr DH (1984) Feeding and growth of the pearl oyster Pinctada margaritifera (L.) in Dongonab Bay, Red Sea. Hydrobiologia 110:241-245

Niquil N (1998) Etude par la modélisation du fonctionnement et de la stabilité du réseau trophique planctonique d'un lagon d'Atoll (Takapoto, Polynésie Française). Thèse de Doctorat de l'Université de Perpignan

Niquil N, Jackson GA, Legendre L, Delesalle B (1998) Inverse model analysis of the planktonic food web of Takapoto Atoll (French Polynesia). Mar Ecol Prog Ser 165:17-29

Ohman MD, Snyder RA (1991) Growth kinetics of the omnivorous oligotrich ciliate Strombidium sp. Limnol Oceanogr 36:922-935

Partensky P, Hess WR Vaulot D (1999) Prochlorococcus, a marine photosynthetic prokaryote of global significance. Microbiol Molec Biol Rev 63:106-127

Paulmier G (1972) La nutrition des huitres en relation avec les sources trophiques. Rev Trav Inst Pêches Marit 36: 456-506

Pomeroy LR (1974) The ocean's food web, a changing paradigm. Bioscience 24:499-504

Porter KG, Feig YS (1980) The use of DAPI for identifying and counting aquatic microflora. Limnol Oceanogr 25:943-948

Porter KG, Pace ML, Battey JF (1979) Ciliate protozoans as links in freshwater planktonic food chains. Nature 277: 563-565

Pouvreau S, Jonquières G, Buestel D (1999) Filtration by the pearl oyster Pinctada margaritifera, under conditions of low seston load and small particle size in a tropical lagoon habitat. Aquaculture 176:295-314

Pouvreau S, Bodoy A, Buestel D (2000) In situ feeding behaviour of the pearl oyster, Pinctada margaritifera: combined 
effects of body size and weather-related seston composition. Aquaculture 181:91-113

Putt M, Stoecker DK (1989) An experimentally determined carbon:volume ratio for marine 'oligotrichous' ciliates from estuarine and coastal waters. Limnol Oceanogr 34: 1097-1103

Renon JP (1977) Zooplancton du lagon de Takapoto (Polynésie française). Ann Inst Océanogr 53:217-236

Ricard M, Guérédrat JA, Magnier Y, Renon JP, Rochette JP, Rougerie F, Sournia A, Wauty B (1979) Le plancton du lagon de Takapoto. J Soc Océanistes 62:47-57

Riisgård HU (1988) Efficiency of particle retention and filtration rate in 6 species of Northeast American bivalves. Mar Ecol Prog Ser 45:217-223

Sakka A (1999) Structure et dynamique de la communauté planctonique dans le lagon de l'Atoll de Takapoto (Archipel des Tuamotu, Polynésie française). Thèse de l'Université Laval

Sherr BF, Sherr EB, Fallon RD (1987) Use of monodispersed; fluorescently labelled bacteria to estimate in situ protozoan bacterivory. Appl Environ Microbiol 53:958-965

Sherr EB, Sherr BF, Paffenhöfer GA (1986) Phagotrophic protozoa as food for metazoans: a 'missing' trophic link in marine pelagic food webs? Mar Microb Food Webs 1: 61-80

Sherr EB, Caron DA, Sherr BF (1994) Staining of heterotrophic protists for visualisation via epifluorescence microscopy. In: Kemp PF, Sherr BF, Sherr EB, Cole JJ (eds)

Editorial responsibility: Fereidoun Rassoulzadegan, Villefranche-sur-Mer, France
Handbook of methods in aquatic microbial ecology. Lewis Publishers, Boca Raton, p 213-227

Sournia A (1977) Analyse et bilan de la production primaire dans les récifs coralliens. Ann Inst Oceanogr 53:47-74

Sournia A, Ricard M (1976) Données sur l'hydrologie et la productivité du lagon d'un atoll fermé (Takapoto, Iles Tuamotu). Vie Milieu 26:243-279

Stoecker DK, Egloff DA (1987) Predation by Acartia tonsa Dana on planktonic ciliates and rotifers. J Exp Mar Biol Ecol 110:53-68

Torréton JP, Dufour P (1996) Temporal and spatial stability of bacterioplankton biomass and productivity in an atoll lagoon. Aquat Microb Ecol 11:251-261

Verity PG (1986) Growth rates of natural tintinnid populations in Narragansett Bay. Mar Ecol Prog Ser 29:117-126

Wright SW, Jeffrey SW, Mantoura RFC, Llewellyn CA, Bjørnland T, Repeta D, Welschmeyer N (1991) Improved HPLC method for the analysis of chlorophylls and carotenoids from marine phytoplankton. Mar Ecol Prog Ser 77: 183-196

Yukihira H, Klumpp DW, Lucas JS (1998) Effects of body size on suspension feeding and energy budgets of the pearl oysters Pinctada margaritifera and P.maxima. Mar Ecol Prog Ser 170:120-130

Yukihira H, Klumpp DW, Lucas JS (1999) Feeding adaptations of the pearl oysters Pinctada margaritifera and $P$. maxima to variations in natural particulates. Mar Ecol Prog Ser 182:161-173

Submitted: September 20, 1999; Accepted: May 26, 2000

Proofs received from author(s): September 14, 2000 